This is the accepted version of the article:

Santos, Sofia José; Garraio, Júlia; Carvalho, Alexandre de Sousa; Amaral, Inês (2021),

"A Space to Resist Rape Myths? Journalism, Patriarchy and Sexual Violence", European

Journal of Women's Studies. DOI: 10.1177/13505068211048465

Published version available at:

https://doi.org/10.1177/13505068211048465

\title{
A space to resist rape myths? Journalism, patriarchy and sexual violence
}

\author{
Sofia José Santos \\ Faculty of Economics, University of Coimbra, Coimbra, Portugal \\ Centre for Social Studies, University of Coimbra, Coimbra, Portugal \\ Júlia Garraio \\ Centre for Social Studies, University of Coimbra, Coimbra, Portugal \\ Alexandre de Sousa Carvalho \\ Centre for Social Studies, University of Coimbra, Coimbra, Portugal \\ Inês Amaral \\ University of Coimbra Faculty of Arts and Humanities, Coimbra, Portugal \\ Communication and Society Research Centre, University of Minho, Braga, Portugal
}

\begin{abstract}
In September 2018, a controversial judicial sentence concerning sexual violence caused a public outcry in Portugal. The court decision invoked the alleged environment of mutual seduction, the use of much alcohol consumption, and the lack of serious injuries to justify the suspended penalty. Stemming from the idea that understandings of what journalism is and what it should be are profoundly ideological and that notions of what it means to be and to behave like a woman and as a man have been developed (and altered over time) based on shifting realities within generalised patriarchal structures, this article intends to critically analyse the news media coverage of the controversial judicial sentence on this rape case in Portugal exploring the implications objective-based journalism entails for gender equality. As such, it will identify the shortcomings of objectivity and its leeway when covering sexual violence exploring how objective-based journalism provides room to (re)negotiate practices, norms, identities, and meanings concerning sexual violence, particularly rape and rape myths, and questioning whether a margin of maneuvre is enough to deconstruct patriarchal assumptions of feminity, masculinity and sexuality.
\end{abstract}

Keywords: Media, sexual violence, journalism, rape, Portugal 


\section{Introduction}

Stemming from the idea that both understandings of what journalism is and what it should be as well as notions of what it means to be and to behave as a woman and as a man are profoundly situated and ideological, this article explores the role modern journalist practices play in rendering rape (in)visible as sexual violence. Through cross-referencing criteria of the journalism embedded in what is coined as "international media culture" (Hallin and Mancini, 2004) with patriarchal assumptions and imaginaries of masculinity, femininity, sexuality and sexual entitlement, this study explores how mainstream journalism guidelines, namely the concept of objectivity and its leeways, are prone to contribute to perpetuating patriarchal structures in societies while embodying, nevertheless, and at the same time, a space to resist patriarchy and sexual violence. To do so, this article turns to Portugal, and specifically to the mainstream coverage of a controversial judicial sentence concerning sexual violence that took place in September 2018 and caused a public outcry as the court decision invoked the alleged environment of mutual seduction, the use of much alcohol consumption, and the lack of serious injuries to justify the suspended penalty.

Portugal is a compelling case as it is a semi-peripheral country whose journalism is unsurprisingly informed by the "international media culture", ${ }^{1}$ and despite being on par with many other EU countries concerning gender equality in health and work (EIGE, 2019), Portugal's reported rape crimes are still a public concern with different studies showcasing its pervasiveness in Portuguese society. For example, one-third of university students in the metropolitan area of Lisbon have been victims of physical sexual violence at least once in their lifetime (Expresso, 2019) and 94.1\% of the women surveyed in the university community of Coimbra have been the target of sexual harassment, while $10.4 \%$

have reported having been raped (UMAR, 2021). Overall, rape crimes in the country have increased 3.3\% between 2017 and 2018 (GSG, 2018), and in 2019 it still represented $11.5 \%$ of all reported sexual crimes (APAV, 2019). Also, Portugal's record in tackling sexual violence tends to be weak and inadequate partly due to the fact that the judicial system remains pervaded by rape myths with serious implications concerning justice and social imaginaries (Ventura, 2018). With various nuances, the Portuguese case offers a valuable contribution to exploring the tensions and (re)negotiations between pretensions of objectivity of journalistic practice and challenges of reporting sexual violence in a way that does not reproduce rape myths. 
The relevance of this topic lies fundamentally on the idea that as the images, representations, and narratives used by the media profoundly shape one's knowledge (McCombs and Shaw, 1972; Shoemaker et al., 2001), the nature of the media information the general public has access to, and the way the media information is produced and circulated is critical to comprehend which narratives and understandings are favoured and, hence, rendered cumulatively dominant, shaping society. Representations and notions of masculinities, femininities, sexuality and rape are no exception to this.

Information-wise, in western modern times, journalism is vital in providing information through news reports and stories on recent events that are of public interest, namely gender-based stories. To support their editorial decisions and the boundaries defining the coverage (i.e. what is and what is not news and how a specific event, group or idea should be framed), ${ }^{2}$ journalists resort to legislation but also to a set of professional, ethical and deontological rules which have been crafted, perfected and conventionally accepted as inescapable guidelines to inform what is conceived as competent journalist practice, thus accounting "who is, or is not a journalist" (Jukes, 2018: 1030-1031). ${ }^{3}$

Although different models of journalism emerged across History and geographies, reflecting and adapting to the wider context of each society, "anglo-saxon" journalism practices have unsurprisingly become dominant as liberal models expanded worldwide, particularly after the end of the Cold War. With this consolidation, journalism's practices focused on the "separation of news and commentary and emphasis on information, narrative, sensation, and entertainment, rather than ideas" became gradually the norm, making journalism based upon objectivity dominant (Hallin and Mancini, 2004: 552), and objectivity a symbol defining the profession (Jukes, 2018).

Objectivity's rationale can be summed up by the journalistic capacity to depict reality as it is, not taking any sides, and leaving to the audiences the exercise of forming an opinion on the topics, issues or groups that are being reported. Although usually explicitly invoked, objectivity can also take the form of other (at times interchangeable) similar concepts, such as impartiality, non-partisanship, balance, detachment, accuracy, and neutrality (Jukes, 2018). These values render representations produced through journalistic mediation to be seen by audiences as the closest to reality and, hence, most likely absorbed as such. However, as language as representation is a construction of meanings through language as a representational system (Hall, 1997), journalism cannot provide objective accounts of events, groups or topics and faithfully and neutrally reflect 
a given reality. Language exists as practice in speech acts which are part of a communication moment and hence operate as performative acts in a given social context framed by particular power relations. If today's societies are based upon generalised (even if at times shifting) patriarchal structures, "objective-based" sexual violence coverage is more prone to chose the side of the perpetrator. This article intends to identify the shortcomings of objectivity and its leeways when covering sexual violence while at the same time exploring how this international journalism culture provides room to (re)negotiate practices, norms, identities and meanings concerning sexual violence, particularly rape and rape myths, and ultimately to question whether a margin of manoeuvre is enough to deconstruct patriarchal assumptions of feminity, masculinity and sexuality.

\section{Patriarchy, journalism and the feminist critique on the specificities of covering sexual violence}

Being socially unfair (Edley and Wetherell, 1995), patriarchy represents and reflects the institutionalization of male dominance in a hierarchy "with very high correlations between position and gender" (Galtung, 1996: 40), influencing the practice and perceptions of sexual violence. In fact, masculinities and femininities represent imagined ideals which are socially constructed, defined on a binary and relational basis, and based upon generalised patriarchal structures (Connell, 2005). Within patriarchy, rape is conventionally perceived in text or subtext as a result of male sexual urge (Brownmiller, 1975). Feminists though understand sexual violence not as something peripheric or deviant in patriarchal cultures, but rather as a key element in patriarchy as a system of control and oppression (Brownmiller, 1975). Conceptions that link what it means to be, behave and express as "a real man" with sexual audacity, dominance and the exercise of violence underpin some of the most pervasive rape myths (Schwendinger, 1974) in our

societies. By rape myths we understand those cultural presuppositions and expectations about sexual assault which are ingrained in the symbolic and normative sphere of societies, and which contribute to excuse and/or invizibilize some forms of sexual aggression, ultimately creating hostility towards some victims. Rape myths are deeply embedded in the social fabric and are normalized and perpetuated through discourse both as language and normative system. As media are grounded in society, they simultaneously reflect and produce the reality one lives in (Goffman, 1974; McCombs 
and Shaw, 1972; Shoemaker et al., 2001). Femininities, masculinities and sexuality are no exception to this (re)production power of the media. Within media, journalism is pivotal in performing these mirroring and producer roles as it is envisaged as an accurate and reliable updated source of relevant information for society.

\section{Objectivity and its leeways as a cornerstone of the international journalism culture}

Understandings of what journalism is, what it should be and how to do it are profoundly ideological and rely on a particular comprehension of the connections to be established between sources, stories and the consequences of what is reported (Hanitzsch, 2007; Lynch and McGoldrick, 2005). Traditionally, journalism is conceived as "the exercise of a practical craft, which delivers the required institutional product, characterised by a high degree of objectivity, key marks of which are obsessive facticity and neutrality of attitude" (McQuail, 1987: 145). Even if "not all journalists believe they should be objective in their work (...) the belief is widespread" (Schudson, 1978: 9), emerging as a professional canon (Lee, 2015) and cumulatively granted a universal hegemonic status (Hanitzsch, 2007: 368). In fact, despite the existence of different journalism traditions, the "Liberal Model" of journalism successfully expanded, leading to the homogenization of journalism practice, particularly in Western newsrooms (Hallin and Mancini, 2004: 252-254). As the "Liberal Model" hegemonically affirmed itself worldwide, the homogenization of journalism practice and the creation of an "international media culture" consolidated (Ibidem).

Being information-oriented, the concept of objectivity has been ever since pivotal within this culture. Conceptually, objectivity revolves around ideals of impartiality and precision. As a professional norm concerning journalism, it became entangled with the values of fairness, accuracy, balance, and detached, fact-based reporting (Bennet, 2003), providing journalists a series of instruments and a beacon for competent and recognized journalism. Concerning practical guidelines, objectivity can be assured by different elements which relate in a self-sustained logic, namely: the inverted pyramid style (Mindich, 1998), the primacy of events over processes (Lynch and McGoldrick, 2005), and the dismissal of "why" questions and indexing of institutional sources (Bennet, 2003; McGoldrick, 2006), and favouring neutral language (Lynch and McGoldrick, 2005). 
Concerning news stories on crime and violence conventional journalism tend to favour atypicality (chose the unexpected or shocking), simplicity (organise reality through an analytical grid that renders it easily comprehended), personification (focus on individuals and not structures), and the status quo eliciting competing perspectives (Sacco, 2005). News coverage of sexual violence has insistently taken this type of coverage in mainstream media, opting for "episodic framing", dismissing the wider power structures and relations, with clear implications on how audiences perceive gender roles and identities, sexuality, entitlement, and gender (in)equality (Sutherland et al., 2016). Indeed, the choice for objectivity in covering sexual violence is situated. Taking cue on Juke (2008), to assume that portraying reality in an objective way corresponds to a depiction of reality that doesn't take sides seems to presume that reality is in itself given and to deny its social construction which is, in turn, imbued with structural and conjuncture power relations. By guiding journalists to depict reality as it is, focusing on facts and dismissing processes, subaltern voices, implications and wider contexts, dominant journalism contributes to the naturalisation of oppressive and violent social relations, phenomena, and systems and the way they interrelate each other (Galtung and Ruge, 1965; Lynch and McGoldrick, 2005).

\section{Feminist scholarship critique: language and representation}

Feminist scholarship since the 1970s was decisive in rebuking the understanding of rape as a biology-driven phenomenon resulting from male sexual urges and disseminating its understanding as a constitutive structure of patriarchy, and crucial for the oppression of women (Brownmiller, 1975) and in the perpetuation of rape myths, which are deeply embedded in the social fabric and are normalized and perpetuated through discourse both as language and normative system. Within this framework, the discursive power the media entail makes them critical. Indeed, media studies about the coverage of rape stories have been corroborating two key observation in Brownmiller's seminal work regarding the discourse construction of the victim $(1975,336 \mathrm{ff}$.): first, there is a media's persistent correlation between violence and desire, which perpetuates the myths that claim that rape is a crime driven by passion and that the seeds of destruction are in the beauty of the victim. Instead of exposing rape as an act of violence and male control (the perception of the victims), rape is persistently invested with sexual desirability and framed as sex; second, victims from underprivileged sectors and racial minorities tend to be ignored. 
Hence, the reporting simply perpetuates both the objectification of raped women as objects of sexual consumption and the existing social hierarchies. Also, and accordingly, as research informed by critical race theory exposes, societies marked by ethno-racial tensions and inequalities tend to invest on rape cases as generators of "moral panic" (Cohen, 2011) - consider, for instance, the phobias of the "black rapist" and the "Arab rapist" in Western societies -, which reinforce the existing social structures and racial hierarchies (Grewal; 2016).

The adopted language is therefore of the uttermost importance when critically examining rape in media discourse. Higgins and Silver observation - "who gets to tell the story and whose story counts as 'truth' determine the definition of what rape is" (Higgins and Silver, 1991: 1) - poses major challenges to journalism, challenging its claims of objectivity (in the sense of neutrality) when reporting about sexual violence. Since rape is a subjective experience which is situated in time and space and is framed by the existing power structures, writing about rape implies not only struggling with perspectives over the meaning of the event and selecting or privileging some perspectives over others, but also navigating in entrenched social imaginaries regarding sexuality, masculinity and femininity. The framing and the rhetorics of representing the events and the actors involved in acts of sexual violence (e.g. erotization, voyeurism, demonization, othering, race and ethnicity constructs) (re)produce and/or contest rooted imaginaries and (trans)national narratives. Indeed, a major contribution by feminist scholarship to the analysis of the media coverage of sexual violence has been its engagement in exposing, deconstructing, resisting and combating the role of media in the perpetuation of rape myths and the invisibilization of rape as violence (e.g. Sacks, Ackerman and Shlosberg, 2018). The focus on the consumption of alcohol is a pervasive strategy of "re-gendering rape $[\ldots]$ as a problem of female drinking rather than male sexual violence" (Meyer, 2010: 19).

\section{Feminist journalism and the coverage of gender-based violence}

As public service, the role of the news media concerning gender-based violence is to stir the public discussion on the topic and mostly on the root causes of the phenomena and on the approaches to tackle this form of violence (Dekić, 2017), a goal that western journalism guidelines, as crafted and perfected throughout the twenty and twenty-first centuries, make difficult to achieve. Facing this, different NGOs and networks produced 
several good practices guidelines aiming to provide instruments and methodologies to journalists and enable them to produce content in a logic of deconstruction and prevention of sexual violence, hence contributing to greater gender equality (e.g. Dart Center, 2011; Femifesto and Collaborators, 2015; Garcia-Rojas, 2012; Minnesota Coalition Against Sexual Assault, 2013; Simpson and Coté, 2006).

On par with these, several movements launched a greater challenge to dominant journalism, calling not for reform within the rules of the establishment, but for rethinking, deconstructing and building a new model of journalism taking into account feminism, peace, anti-racism, and/or economic solidarity as their agenda. As one of the most comprehensive, the Peace Journalism model is commonly highlighted by literature in the area. It not only challenged the canons of modern journalism denouncing the ways in which it ends up voluntarily or involuntarily, explicitly or implicitly, sustaining power relations and violence, but it also presents methodologies and tools to cover events such as sexual violence, in a more analytical, transformative and preventive way, thus conducive to social transformation. Recognising an implicit gender perspective in the Peace Journalism model, Yiping (2012) proposes a specific gender-based model, providing the tools for a (de)constructive, plural and simultaneously reactive/preventive coverage of sexual violence, while questioning mainstream journalistic practices concerning gender-based violence.

At the same time, despite many feminist journalists work in mainstream media, feminist media outlets have been burgeoning providing "content advocating expanded political, social, and cultural roles for women (...) [exposing] gender oppression, which is understood to be interstructured with oppression especially by race, sexual orientation, and class, but also by ethnicity, religion, and other bases of invidious distinction" (Steiner, 2020). Examples of these projects are augmenting concerning numbers and editorial choices, particularly in the digital realm. Concerning sexual violence, they tend to promote the (in)visibility of sexual violence and the reproduction of imaginaries regarding masculinity and femininity which make rape (im)possible.

\section{The case of the mediatic judicial decisions on the Gaia disco case in Portugal}

Portuguese media coverage of sexual violence reproduces the aforementioned major traits examined by feminist scholarship. Portuguese legislation underwent major changes in the 
last decades and is now in pair with EU and international norms regarding gender equality and the protection of women and girls. Nonetheless, rape myths still pervade society and State's institutions and key moments of feminist outcry were provoked precisely by judicial sentences which exposed entrenched rape myths. In 1988, a sentence concerning the kidnap and rape of two tourists referred to the behavior of the victims as mitigating factors for the aggressors. According to the judge, they should have known better than hitchhiking and getting into a car with two young native men in the "hunt area of the Iberian macho". The judge's mindset is not an exception in the Portuguese context. Ventura's (2018) seminal work on Portuguese justice system handling of sexual violence exposes how the tendency to have sentences determined by the scrutiny of the morals and social position of aggressors and victims goes well into the 21st century. Sexual aggressions committed in a public place by a stranger who has no respected social position (no sex appeal, no family life and from a poorer background, unemployed or with low paid jobs) have a higher probability of conducting to rape sentences, while aggressors with respected social positions (good job, good father, good husband, good friend) are less likely to be convicted. Similarly, the morals and behaviour of the victims continue to be a decisive factor: women perceived as promiscuous and who do not suffer severe vaginal injuries are less likely to be believed in court and are oftentimes suspected of alleging rape for situations involving a certain degree of seduction and consent. As we will see, Gaia's sentence corroborates precisely Ventura's findings regarding the persistent blurring/confusion in the Portuguese judiciary between consent (seduction) and nonconsent (rape) (2018: 326).

Journalism-wise, despite informed by French journalistic tradition and being closer to Italy and Spain than to any other northern European country (Santana-Pereira, 2016), Portuguese journalism is informed by what has been conceptualised as "western journalism" (Sousa, 2008) fitting the so-called "international media culture" (Hallin and Mancini, 2004). While this has been a general global trend - the immolation of the liberal model - the fact that Portugal is a western semi-peripheral country makes it even more susceptible to subscribe and embody the hegemonic understanding of what a journalist is and how his or her work should be put forward to be rigorous and, thus, successful.

The case dates back to the 27 th November 2016, to a disco in the northern city of Vila Nova de Gaia, close to Oporto. According to the judgement, ${ }^{4}$ after drinking several alcoholic beverages and having stayed inside the club until its closure, the victim had lost consciousness in the disco's toilet and was then sexually abused - first by the bartender 
and afterwards by the nightclub concierge. The defendants - aged 39 and 25 years old were sentenced to four and a half years in prison with a suspended sentence. The decision was justified with the fact that, despite condemning their conduct, the physical damage caused was, accordingly, not particularly serious; there hadn't been any contact between the victim and the defendants; and both the defendants had no criminal record and were integrated into society. The judicial decisionshould then be envisaged, according to the judge, as a solemn warning to prevent recidivism. The sentence echoes persistent rape myths: attributing to the victim part of the responsibility for what happened (e.g. alcohol consumption; attitudes and contexts suggestive of promiscuity and seduction); devaluing the damage of the assault by the absence of vaginal lesions, implying non-sexual resistance or habituation. The case came to media attention when the sentence was issued, creating a turmoil concerning sexual violence, consent and judicial decisions on those matters.

\section{Methods and corpus of analysis}

We choose a highly controversial judicial sentence concerning sexual violence which took place in Portugal in 2018, opening the way for a broader national discussion on the topic of \#metoo. To analyse the newspaper media coverage of this case, we selected three online newspapers - Correio da Manhã (CM), Observador e Público - which hold different editorial lines and are, hence, representative of distinct national audiences. While CM serves as a tabloid and Público and Observador as broadsheet; Público is perceived to be centre-left while Observador is labelled as right-wing. To put our analysis forward we selected all news articles published within a time frame of ten days after the judicial sentence was issued (i.e. 20-29th September 2018); subsequently, we narrowed our corpus through the use of the following cumulative tags: (i) "rape"; (ii) "sexual violence"; (iii) "Gaia"; and (iv) "Oporto Court of Appeal". ${ }^{5}$ We then further narrowed the

selected articles to those covering the Gaia rape case as the main story. Overall, we collected 17 online news articles produced by the three aforementioned Portuguese online newspapers (Table 1).

To analyse the articles we undertook a general analysis on how each of the newspapers covered the judicial decision and we checked whether each news piece complied with the dominant journalism model: using the inverted pyramid writing style; privileging institutional sources, favouring events over processes, dismissing the 'why' question, and 
favouring neutral and unbiased language - and explored how those journalistic choices impacted how rape is represented and how specific assumptions and imaginaries of masculinity, femininity, sexuality and sexual entitlement reported (explicitly or implicitly) in this news contributed to render rape as sexual violence (in)visible as such.

Table 1. Number and volume of sample's articles per newspaper (percentage numbers rounded to two decimals).

\begin{tabular}{|c|c|c|c|c|c|c|}
\hline \multirow[b]{2}{*}{ Newspaper } & \multirow[b]{2}{*}{ Number } & \multirow{2}{*}{$\begin{array}{l}\text { Volume } \\
(\mathrm{N}=17)\end{array}$} & \multicolumn{2}{|l|}{ Number } & \multicolumn{2}{|l|}{ Percentage } \\
\hline & & & $\geq 501$ words & $\leq 500$ words & $\geq 501$ words & $\leq 500$ words \\
\hline Correio da Manhã & 4 & $23.53 \%$ & 3 & 1 & $17.65 \%$ & $5.88 \%$ \\
\hline Observador & 4 & $23.53 \%$ & 3 & 1 & $17.65 \%$ & $5.88 \%$ \\
\hline Público & 9 & $52.94 \%$ & 7 & 2 & $41.18 \%$ & $11.76 \%$ \\
\hline Total & 17 & $100 \%$ & 13 & 4 & $76.48 \%$ & $23.52 \%$ \\
\hline
\end{tabular}

Analysis

In general terms, the news coverage of the three newspapers subscribed to the dominant journalism practice embedded in the "international media culture" (Hallin and Mancini, 2004), and the news coverage tended to include the same topics of the news story. However, the approaches to those topics and the verbal and visual language used by the three newspapers were distinct and with a different contribution to representations and imaginaries concerning rape, sexual violence and, ultimately, gender (in)equality. Observador published four news stories: one focused on the sentence (one day after Público reported it), one on sex crimes conviction rates, one on judges' support towards the sentence and one about another possible case in the same disco. Whenever covering the judgement decision, Observador hardly offered competing opinions on what the judge's decision could/should have been. Concerning photos, Observador chose three different photos to frame their news reports: one on details of a courtroom, two others on drinking at night. The same photo was used for two of the news reports. In turn, CM restricted its coverage to a fact-based selection, and whenever a more in-depth coverage was chosen, the newspaper invested mostly in sensationalist considerations (e.g. sexual details in the text of the judgement). Among the four news articles, one focused on the sentence (one day after Público reported it), two on feminist protests and one on another 
possible case in the same disco. Only this last one was accompanied by a photo - an investigation policeman from behind. Through covering these different topics of the story, the newspaper tried to include the different sides of the story, even if it did not provide in-depth coverage. Finally, Público was the first newspaper to publish the story and the one providing it more space, while giving the floor to different voices. Concerning coverage, Público published one article accounting for the sentence and one providing the general context of rape cases on trial in Portugal, two showcasing the support of judges' unions to the sentence and integrating criticisms by lawyers and activists to the reactions of the Union of Judges; and five focused on feminist protests and criticisms of the sentence. There was an effort to make this fait-diver an emblematic case to denounce the structural nature of the story. Concerning authorship, out of the nine news items, five are from female journalists (one in collaboration with a male journalist). Concerning photos, Publico's focused on the feminist protests against rape culture: out of the nine pieces of Público, six have photos of feminist protests and/or anti-rape slogans; the other three include a picture of a tribunal's façade, the inside of a disco and the picture of a Portuguese jurist (Table 2).

Table 2. Topics and numbers of news articles within the Gaia's disco story covered by each newspaper.

\begin{tabular}{lll}
\hline Newspaper & Covered topics of the story & $\begin{array}{l}\text { No of } \\
\text { articles }\end{array}$ \\
\hline $\begin{array}{c}\text { Correio da } \\
\text { Manhã }\end{array}$ & $\begin{array}{l}\text { The judicial sentence } \\
\text { Another sexual assault in that same disco } \\
\text { Feminist protests and other criticisms concerning the judicial } \\
\text { sentence }\end{array}$ & 2 \\
Observador & $\begin{array}{l}\text { The judicial sentence } \\
\text { Another sexual assault in that same disco } \\
\text { Support of judges/unions concerning the sentence }\end{array}$ & I \\
& $\begin{array}{l}\text { Sex crimes conviction rates } \\
\text { The judicial sentence }\end{array}$ & I \\
& $\begin{array}{l}\text { Support of judges/unions concerning the sentence } \\
\text { Contextualisation/Patriarchal structures in society } \\
\text { Feminist protests and other criticisms concerning the judicial } \\
\text { sentence }\end{array}$ & 2 \\
\hline
\end{tabular}

Concerning norms sustaining and guarding objectivity as a professional norm, all 17 news articles followed the structure of the inverted pyramid writing style. In event-based news, the structure shed primarily light on the events of "rape", "conviction", "support" or "contestation" (depending on the covered event) and the alleged facts sustaining the story. 
Secondary importance was given to the context, nuances or policies aimed to change the status quo. For example, the need to enhance training for judges and state prosecutors is included in the last paragraph of the article, ${ }^{6}$ creating the conditions, in a mimetic logic, for key information on these topics to be dismissed as less important. The same happened with the distinction between «sexual abuse" and «rape» ${ }^{7}$ which CM's article only superficially mentions at the end of the news article, or with the recalling of a previous sexist sentence of the Oporto Court of Appeal concerning gender-based violence $^{8}$ mentioned in the 5th paragraph of a Público's seven paragraphs article. All these topics would be essential to deconstruct patriarchy as structure and to approach pivotal issues concerning sexual violence, such as "rape", "consent", "masculinity", "femininity", and "justice".

In terms of sources, all 17 articles allude to institutional sources to substantiate the information they disseminate, and the majority dismisses sources which do not represent law enforcement agents or institutions. Main sources referred to include courts, judicial civil servants and police enforcement. Specifically, the communiqué of the Oporto Court of Appeal, ${ }^{9}$ the judgement decision, ${ }^{10}$ and police reports are frequently quoted in the coverage undertaken by the three newspapers. Most of the news articles just relied on the Court decision or sources supporting it. This is quite evident in one CM's article ${ }^{11}$ and in three articles of Observador. ${ }^{12} 1314$ Fewer news pieces include civil society organisations like National Association of Portuguese Judges, which supported the decision, and APAV as well as the feminist UMAR and Coletiva which represent contestation voices concerning what the court's decision as well as the court's text and subtext on what entails "sexual violence", "being a man", "being a woman", and "rape". Only one news article from Público ${ }^{15}$ reached out to expert analytical knowledge, and only two from $\mathrm{CM}^{1617}$ and seven from Público's 192021222324 made an effort to put the different narratives and perspectives in confrontation, thus guaranteeing more plural information to their readers. This is even more relevant as the status quo is patriarchal and to deconstruct it, engaging different enunciation locus, experiences and knowledge is fundamental.

From the 17 articles, 14 favoured the preference for events over processes (those events being: the judicial decision, the rape, the contestation or the support to the judicial decision). Most events coverage lack contextualisation concerning what happened. The news event is seldom presented and understood by audiences as the result of wider structures and power relations, but rather as an isolated event. The construction of "rape" 
as an isolated media narrative, ellipses patriarchal social imaginaries and relations from the public debate and invisibilizes the need of public policies and social change to tackle sexual violence and promote gender equality. Despite this general trend, there were three exceptions: two in Público ${ }^{25} 26$ and one in Observador. ${ }^{27}$ In the case of the first Público's article, ${ }^{28}$ the news piece intends to show that the rape which happened (this time) in Gaia is no exception, but rather a standard. It also refers to the data of the Ministry and reaches out to academics aiming at debunking the "tradition" and "history" argument that conventionally intends to explain or even excuse rape.

There is also a trend to dismiss the "why" question. Prominence was given to the "What?" "Who?" "How?" "When?" "Where?" questions. Even articles which used statistics to give broader contextual background on the topic of sexual violence (e.g, Público ${ }^{29}$ Observador ${ }^{30}$ ) dismissed any interpretation of the presented data. The dismissal of the "why" questions in this case implies a passive acceptance of the structural and deep-rooted social causes of rape and traditional criminal justice options and validates linear formulations of rape, gender imaginaries from which rape emerges and might be excused, and the politics tackling it. The exception to this trend was a Público's article $^{31}$ which included information aiming at partially explaining why rape crimes (still) happen, and how judicial sentences such as the one reported are nowadays issued in Portugal.

Finally, concerning neutral language, all 17 news articles are fact-based. This method, in theory, allows publishing a news article without any bias, prejudice or agenda. However, to choose fact-based precision is to dismiss that objective reality is nothing less than the product of structural and contextual power structures as well as individual subjectivities (including the position in gender, class, race and other social constructed hierarchies) which are, in turn, perceived and interpreted according to ideational structures and enunciation locus. As such, neutral and fact-based depictions always take sides, even if involuntarily. Within this sample, one of the examples of "neutral language" usage can be found in the coverage of the sentence, where alcohol, unconscious and unable to resist (or respective synonyms) are found throughout the texts as they appear in the Court decision, but the newspapers take it differently. Observador ${ }^{32}$ and Público ${ }^{33}$ use more often the concepts that pull more towards "inability to consent/resist". In CM's news article, ${ }^{34}$ the newspaper reproduces both the verdict text and subtext using direct and indirect quotes. By replicating the verdict without challenging it or confronting it with competing perspectives, this news piece tends to reproduce the verdict itself, namely the 
ideas that caused a national outcry, that is the usage of language through which responsibility was attributed to the victim as, accordingly, she was misbehaving (e.g. alcohol consumption and kissing) while positive (e.g. support the drunk victim) and exculpatory behaviours (mutual seduction; risk of incidence is reduced) were attributed to the perpetrators, which are thus perceived as less aggressive or mean. Even though the article describes the judgement as controversial, it does so without actually challenging it. By striving for neutrality and objectivity, the news reproduces power relations that make the victim co-responsible and exonerate the perpetrators. Taking a cue from Desmond Tutu's famous quote, neutrality here is merely sidelining with the dominant patriarchal perspective (Table 3).

Table 3. Number of times each word (or synonyms) was used in each news article of selected newspapers covering the court decision.

\begin{tabular}{lllll}
\hline & & \multicolumn{2}{l}{ Number of times each word was used } \\
\cline { 3 - 5 } \cline { 3 - 5 } Newspaper & $\begin{array}{l}\text { Size of the news } \\
\text { article in words }\end{array}$ & $\begin{array}{l}\text { Alcohol (or } \\
\text { synonym) }\end{array}$ & $\begin{array}{l}\text { Unconscious (or } \\
\text { synonym) }\end{array}$ & $\begin{array}{l}\text { Unable to resist } \\
\text { (or synonym) }\end{array}$ \\
\hline $\begin{array}{l}\text { Correio da } \\
\text { Manhã }\end{array}$ & 481 & 2 & 4 & 1 \\
$\begin{array}{l}\text { Observador } \\
\text { Público }\end{array}$ & 539 & 2 & 7 & 3 \\
\hline
\end{tabular}

In addition, the fact that language is neutral does not mean that the selection of what to report and how to report is unbiased. For example, Observador and Público removed more parts of the sentence describing the aggressors' behaviour (including mentioning the lack of regret), while CM gives more space to the victim's behaviour, thus partly shifting responsibility for what happened.

\section{Discussion}

The role of the news media concerning gender-based violence is to stir the public discussion on the topic, on its root causes, and on the approaches to tackle it (Dekić, 2017). Concerning the Portuguese coverage of the rape in Vila Nova de Gaia's disco, our discussion analyses collected data through exploring the tensions between patriarchal societies; the objectivity requirements of dominant journalism; and the need to challenge gender inequality and rape myths. 
The text of the ruling touches on fundamental questions of how the victims and perpetrators were imagined and the cultural imaginaries revolving gender identities and sexual violence. The issues of consent and female agency as put by the ruling are relevant, most notably the question of alcohol and the idea that rape to be seen, perceived, and addressed as such implies visible physical injuries. Although the law punishes the rape of an unconscious person as rape, common sense still remains often receptive to exculpatory discourses, especially if alcohol or night life is involved. This resonates precisely with entrenched imaginaries which hold women accountable for alcohol consumption and implicitly condescend to the myth of unbridled male sexuality (she provoked them through kissing and they did not resist as if the male desire was naturally uncontrolled after being provoked). In this case, Correio da Manhã and Observador opted to reproduce text, subtext and the imaginaries supporting the polemic verdict without challenging its wording, hence corroborating its assumptions and imaginaries of masculinity, femininity, sexuality and sexual entitlement. The choice for the photos illustrating the news article also reinforces this idea. Moreover, although Correio da Manhã offered its audience competing narratives concerning the crime and the judicial decision, it used the term "sexual abuse" instead of the term "rape", favouring the public perception of the perpetrator and Observador published articles favouring security and judicial forces' voices, encouraging the validation of the judicial decision among its audience. They did so through complying to high traditional journalism standards related to values such as non-partisanship, neutrality, accuracy, or detachment. Nevertheless, seemingly transparent, the option seems to be a dismissive "biased transparency", to use Vine's (2017) term in reverse.

Público was the one that by means of a few news articles put forward an effort to deconstruct the view presented in the judgement through news focused on the protests and on those protesting (e.g. feminists movement, such as UMAR, Colectiva, APAV). Furthermore, Público undertook a research and data analysis that involved listening to experts on sexual violence issues (and not just in the constitution and subtleties of the law) in order to have a broader picture and comprehend the sentence as resulting from a gender ideological perspective that is still pervasive in both Portuguese courts and society. As such, Público constructed the case not to be read as a mere fait-diver or controversial judicial sentence but re-signified it as both a space to contest sexism in Portuguese judicial system and emblem of structural problems. It did so by giving voice to critics, that is the way to build the news contributed to stirring the public debate on the meaning of "consent" and on the naturalization of male entitlement, particularly in cases 
where alcohol is involved. The editorial choice of (a) not disclosing the context in which sexual violence happened, (b) focusing only on the stories that fulfil new values, (c) generally blaming women for that violence (explicitly or implicitly), and (d) resorting to security forces as the only pivotal specialized voices perpetuate myths. It, thus, contributes to the encouragement of beliefs and sexist behaviours, namely the accountability of women's choices and behaviours as a victim of sexual violence perpetrated by men (Sutherland et al., 2016).

Professions always hold subjective and ideological slant. The "concept of objectivity as a measurement of quality journalism ignores the restrictive nature of the practice which shapes it, as well as the bias of values which determine the order and content of reports" (Spencer, 2005: 13). Journalism "professional ideologies" constitute "crystallizations of distinctive arrays of journalism-related values, orientations, and predispositions" that articulate themselves differently giving birth to distinct forms of understanding and practising of journalism (Hanitzsch, 2007: 370). Público's coverage was the one that best contributed to cover the judicial decision on Gaia's disco rape story in a way that challenged patriarchal conceptions of gender identities, sexual violence, and rape. It did so through including processes on par with events, thus exploring to some extent the elsewhere missing "why" questions, and making an effort to go beyond institutional sources and, with that, to provide new voices, parts and perspectives on the topic. Público did so not openly denying western journalism guidelines, but embracing public service and negotiating journalism practices within the established order of things. However, Público's coverage also fell short concerning: involving men and women understood as such in the conversation; exploring visible and invisible effects of sexual violence on both men and in women; exploring how men and women are affected (positively and/or negatively) by rape, and showcase the role of institutional structures in the perpetuation and prevention of sexual violence. Part of these shortcomings can be justified by the straight jacket dominant journalism canon imposes. To think about news coverage of sexual violence, it is important to explore resistances and essential to discuss journalism models that render "rape" visible as sexual violence and that (de)constructs the imaginaries regarding masculinity and femininity which make rape (im)possible. 


\section{Conclusion}

Looking back at the history of journalism in its geographic and political diversity highlights how it operates in a continuum of power, being simultaneously forged by dominant social structures and ideologies and a space to sustain, promote or challenge them. Concerning the analysis undertaken on sexual violence coverage, this article draws two main conclusions. The first goes in line with the main argument of this article: in an attempt to be objective, all three media outlets favoured patriarchal assumptions and imaginaries of masculinity, femininity, thus contributing to render rape as sexual violence (in)visible as such. The second conclusion showcases resistance journalism practices. Within Público, exceptions to mainstream journalism practice were successfully made. As Público showed, journalism can be a privileged space to challenge dominant power relations and interests, namely concerning gender-based violence. Some Público's articles contributed to render rape visible as such, namely through focusing on processes and not only on events and by reaching out to different perspectives and voices beyond institutional ones, thus, amplifying the number of voices heard and democratizing the construction of news (gendered) stories. Also, within the journalism dominant model, Público sought to opt for investigative articles, namely using statistics to show that this was not an isolated story but rather suggestive of a pattern. With these options, it covered the events while also giving the floor to the processes that give rise to sexual violence, and was able to render visible gender-based power relations underlying sexual violence, promoting social change.

\section{Declaration of Conflicting Interests}

The author(s) declared no potential conflicts of interest with respect to the research, authorship, and/or publication of this article.

\section{Funding}

The author(s) disclosed receipt of the following financial support for the research, authorship, and/or publication of this article: This work was supported by the Fundação para a Ciência e a Tecnologia (grant number PTDC/COM-CSS/31740/2017)).

\section{ORCID iDs}

Sofia Jose Santos https://orcid.org/0000-0001-9300-7452

Julia Garraio https://orcid.org/0000-0001-5342-8391 


\section{Notes}

1.For more on this term, cf. McQuail (1987); and Hallin and Mancini (2004: 251-252).

The term entails a "Liberal Model" of journalism which, despite prevailing "in its purest form in North America" has hegemonically expanded, leading to the homogenization of journalistic practice, particularly in Western newsrooms (Hallin and Mancini, 2004: 252-254).

2.See: McCombs and Shaw (1972); Goffman (1974).

3.See: McGoldrick (2006); Hanitzsch (2007); Mindich (1998).

4.See: http://www.dgsi.pt/jtrp.nsf/56a6e7121657f91e80257cda00381fdf/6f7c90fb3d34e 281802582eb0049ac25?OpenDocument.

5.In Portuguese: (i) violação; (ii) violência sexual; (iii) Gaia; (iv) Tribunal de Relação do Porto.

6.Público. "Acórdão que desvaloriza violação é assinado por presidente do sindicato dos juízes", 22/09/2018.

7.Correio da Manhã. Associação de mulheres acusa juízes de misoginia no caso de violação em Gaia, 25/09/2018.

8.Público. "Protesto convocado: "Não aceitamos uma justiça machista!"”, 24/09/2019.

9.Available online here. Retrieved on June 18, 2019.

10. Available online here. Retrieved on June 18, 2019.

11.Correio da Manhã. Juízes dizem que "ilicitude não é elevada" em caso de mulher inconsciente violada por dois homens, 21/09/2018.

12.Observador. "Tribunal considera que caso de jovem violada quando estava inconsciente foi "sedução mútua" e de "mediana ilicitude"”, 21/09/2018.

13.Observador. "Sindicato dos Juízes defende decisão do Tribunal da Relação do Porto e diz que jovem inconsciente não foi violada”, 22/09/2018.

14.Observador. "Jovem terá sido abusada no mesmo bar onde mulher de 26 foi violada em 2016", 29/09/2018.

15.Público. "Acórdão que desvaloriza violação é assinado por presidente do sindicato dos juízes", 22/09/2018.

16.Correio da Manhã. Associação de mulheres acusa juízes de misoginia no caso de violação em Gaia, 25/09/2018.

17. Correio da Manhã. Centenas de pessoas concentraram-se no Porto a pedir o "fim da justiça machista", 26/09/2018. 
18.Público. "Acórdão que desvaloriza violação é assinado por presidente do sindicato dos juízes", 22/09/2018.

19.Público. "Protesto convocado: "Não aceitamos uma justiça machista!"”, 24/09/2019.

20.Público. "UMAR acusa juízes de misoginia no caso de violação em Gaia”, 25/09/2018.

21.Público. "«É violação, não é sedução.» Porto protesta contra sentença do tribunal”, 26/09/2018.

22.Público. "APAV pede mais formação dos magistrados sobre abuso sexual de mulheres", 27/09/2018.

23.Público. "Só 37\% dos condenados por crimes sexuais vão para a prisão", 27/09/2018.

24.Público. "Mulheres Socialistas criticam acórdão que deixou em liberdade violadores de mulher", 28/09/2018.

25.Público. "Acórdão que desvaloriza violação é assinado por presidente do sindicato dos juízes", 22/09/2018.

26.Público. "Só 37\% dos condenados por crimes sexuais vão para a prisão", 27/09/2018.

27. Observador. "Crimes sexuais. Só 37\% dos agressores foram condenados a penas de prisão efetiva", 27/09/2018.

28.Público. "Acórdão que desvaloriza violação é assinado por presidente do sindicato dos juízes”, 22/09/2018.

29.Público. "Só 37\% dos condenados por crimes sexuais vão para a prisão", $27 / 09 / 2018$.

30.Observador. "Crimes sexuais. Só 37\% dos agressores foram condenados a penas de prisão efetiva", 27/09/2018.

31.Público. "Acórdão que desvaloriza violação é assinado por presidente do sindicato dos juízes", 22/09/2018.

32. Observador. "Tribunal considera que caso de jovem violada quando estava inconsciente foi "sedução mútua" e de "mediana ilicitude", 21/09/2018.

33.Público. "Violaram-na quando estava inconsciente, mas tribunal entendeu que o mal feito não é "elevado", 20/09/2018.

34.Correio da Manhã. Juízes dizem que "ilicitude não é elevada" em caso de mulher inconsciente violada por dois homens", 21/09/2018. 


\section{References}

APAV (2019) “Estatísticas APAV. Relatório Anual 2019”, Report. Available at: https://apav.pt/apav_v3/images/pdf/Estatisticas_APAV-Relatorio_Anual_2019.pdf (accessed 1 July 2020).

Bennet, LW (2003) The Politics of Illusion. London: Longman.

Brownmiller, S (1975) Against our Will. Men, Women and Rape. New York: Fawcett Columbine.

Cohen, S (2011) Folk Devils and Moral Panics The creation of the Mods and Rockers. London and New York: Routledge.

Connell, R (2005) Masculinities. 2nd ed. Cambridge: Polity Press.

Dart Center (2011) "Reporting on Sexual Violence". 15-07-201. Available at: https://dartcenter.org/content/reporting-on-sexual-violence (accessed 16 June 2018).

Dekić, S (2017) Media Coverage of Gender-Based Violence - Handbook and Training of Trainers. UN Women. Available at: https://eca.unwomen.org/en/digitallibrary/publications/2017/09/media-coverage-of-gender-based-violence---handbookand-training-of-trainers (accessed 1 November 2021)

Edley, N, Wetherell, M (1995) Men in Perspective: Practice, Power and Identity. London: Prentice Hall.

EIGE (2019) “Index Score for Portugal 2019”, Gender Equality Index. Available at: https://eige.europa.eu/gender-equality-index/2019/PT (accessed 1 July 2020).

Expresso (2019) Um terço dos universitários de Lisboa diz já ter sofrido violência sexual física, 10.12.2019. Available at: https://expresso.pt/sociedade/2019-12-10-Umterco-dos-universitarios-de-Lisboa-diz-ja-ter-sofrido-violencia-sexual-fisica (accessed 4 July 2020).

Femifesto and Collaborators (2015) Use the right words: Media Reporting on sexual violence in Canada. Available at: http://www.femifesto.ca/wpcontent/uploads/2015/12/UseTheRightWords-SingleDec3.pdf (accessed 16 June 2018).

Galtung, J (1996) Peace by Peaceful Means: Peace and Conflict, Development and Civilization. London: Sage.

Galtung, J, Ruge, MH (1965) The structure of foreign news: The presentation of the Congo, Cuba and Cyprus crises in four Norwegian newspapers. Journal of Peace Research 2(1): 64-90. 
Garcia-Rojas, C (2012) Reporting on Rape and Sexual Violence. A Media Toolkit for Local and National Journalists to Better Media Coverage. Chicago: Chicago Taskforce on Violence Against Girls \& Young Women. Available at: chitaskforce.org/wp/wp-content/uploads/2012/10/Chicago-Taskforce-Media-Toolkit.pdf (accessed 16 June 2018).

Goffman, E (1974) Frame Analysis: An Essay on the Organization of Experience. Cambridge, MA, US: Harvard University Press.

Grewal, K (2016) Racialised Gang Rape and the Reinforcement of Dominant Order: Discourses of Gender, Race and Nation. Abingdon: Routledge.

GSC- Gabinete do Secretário-Geral (2018) "Relatório Nacional de Segurança Interna 2018”, Sistema de Segurança Interna. Available at: https:/www.portugal.gov.pt/download-ficheiros/ficheiro.aspx?v=ad5cfe37-0d52-412e83fb-7f098448dba7 (accessed 1 July 2020).

Hall, S (ed.) (1997) Representation: Cultural Representations and Signifying Practices. London: Sage.

Hallin, DC, Mancini, P (2004) Comparing Media Systems: Three Models of media and Politics. Cambridge: Cambridge University Press.

Hanitzsch, T (2007) Deconstructing journalism culture: Toward a universal theory. Communication Theory 17(4): 367-385.

Higgins, L A, Silver, B R (1991) Rape and Representation. New York: Columbia University Press.

Jukes, S (2018) Back to the future. Journalism Practice 12(8): 1029-1038.

Lee, J (2015) The double-edged sword: The effects of Journalists' social media activities on audience perceptions of journalists and their news products. Journal of Computer-Mediated Communication 20(3): 312-329.

Lynch, J, McGoldrick, A (2005) Peace journalism: A global dialogue for democracy and democratic media. In Hackett RA and Zhao Y (eds), Democratizing Global Media: One World, Many Struggles. Lanham: Rowman and Littlefield, pp. 269288.

McCombs, ME, Shaw, DL (1972) The agenda-setting function of mass media. Public Opinion Quarterly 36(2): 176-187.

McGoldrick, A (2006) War journalism and' objectivity. Conflict \& Communication 5(2): 1-7. 
McQuail, D (1987) Mass Communication Theory: An Introduction. London: Sage Publications, Inc.

Meyer, A (2010) "Too Drunk To Say No": Binge drinking, rape and the Daily Mail. Feminist Media Studies 10(1): 19-34.

Mindich, D (1998) Just the Facts: How “Objectivity” Came to Define American Journalism. New York: New York University Press.

Minnesota Coalition Against Sexual Assault (2013) Reporting on sexual violence: a guide for journalists. Available at: http://www.mncasa.org/assets/PDFs/briefbank/2013MediaManual.pdf (accessed 16 June 2018).

Sacco, VF (2005) When Crime Waves. London: Sage Publications.

Sacks, M, Ackerman, AR, Shlosberg, A (2018) Rape myths in the media: A content analysis of local newspaper reporting in the United States. Deviant Behavior 39(9): 1237-1246.

Santana-Pereira, J (2016) The Portuguese media system and the normative roles of the media: A comparative view. Análise Social 51(221): 780-801.

Schudson, M (1978) The ideal of conversation in the study of mass media. Communication Research 5(3): 320-329.

Schwendinger, J R, Schwendinger, H (1974) Rape Myths: In Legal, Theoretical, and Everyday Practice. Crime and Social Justice 1: 18-26. http://www.jstor.org/stable/29765884.

Shoemaker, PJ, Eichholz, M, Kim, E, et al. (2001) Individual and routine forces in gatekeeping. Journalism \& Mass Communication Quarterly 78(2): 233-246.

Simpson, R, Coté, W (2006) Covering Violence: A Guide to Ethical Reporting About Victims \& Trauma. New York: Columbia University Press.

Sousa, JP (2008) Uma história breve do jornalismo no ocidente. In: Sousa, JP (ed.) Jornalismo: História, Teoria e Metodologia. Perspectivas Luso-Brasileiras. Porto: Edições Universidade Fernando Pessoa, pp.12-93.

Spencer, G (2005) The Media and Peace: From Vietnam to the 'War on Terror. New York: Palgrave Macmillan.

Steiner, L (2020) Feminist journalism. In: Vos, TP, Hanusch, F, Dimitrakopoulou, D, et al (eds) The International Encyclopedia of Journalism Studies. Hoboken, New Jersey: Wiley-Blackwell, pp. 1-9. 
Sutherland, G, McCormack, A, Pirkis, J, et al. (2016) Landscapes: Media representations of violence against women and their children: State of knowledge paper. Available at: https://www.anrows.org.au/publication/media-representations-of-violenceagainst-women-and-their-children-state-of-knowledge-paper/ (accessed 15 June 2019).

UMAR (2021) Veredas feministas: Trilhando Caminhos no Combate à Violência Sexual em Coimbra. UMAR: .ISBN: 978-989-53175-0-9. Available at: http://www.umarfeminismos.org/images/stories/noticias/ebook_veredas_02f.pdf

Ventura, I (2018) Medusa no Palácio da Justiça ou uma históia da violação sexual. Lisboa: Tinta da China.

Vine, P (2017) When is a journalist not a journalist?: Negotiating a new form of advocacy journalism within the environmental movement. Pacific Journalism Review 23(1): 43 .

Yiping, C (2012) "Revisiting Peace Journalism with a Gender Lens". ISIS Women. Available

at: http://www.isiswomen.org/phocadownload/print/isispub/wia/wia2012/wia2012_10cimc aiyiping.pdf (accessed 16 June 2018). 